\title{
Basic nursing care: The most provided, the least evidence based - A discussion paper
}

Citation for published version (APA):

Zwakhalen, S. M. G., Hamers, J. P. H., Metzelthin, S. F., Ettema, R., Heinen, M., de Man-Van Ginkel, J. M., Vermeulen, H., Huisman-de Waal, G., \& Schuurmans, M. J. (2018). Basic nursing care: The most provided, the least evidence based - A discussion paper. Journal of Clinical Nursing, 27(11-12), 24962505. https://doi.org/10.1111/jocn.14296

Document status and date:

Published: 01/06/2018

DOI:

10.1111/jocn.14296

Document Version:

Publisher's PDF, also known as Version of record

Document license:

Taverne

Please check the document version of this publication:

- A submitted manuscript is the version of the article upon submission and before peer-review. There can be important differences between the submitted version and the official published version of record.

People interested in the research are advised to contact the author for the final version of the publication, or visit the DOI to the publisher's website.

- The final author version and the galley proof are versions of the publication after peer review.

- The final published version features the final layout of the paper including the volume, issue and page numbers.

Link to publication

\footnotetext{
General rights rights.

- You may freely distribute the URL identifying the publication in the public portal. please follow below link for the End User Agreement:

www.umlib.nl/taverne-license

Take down policy

If you believe that this document breaches copyright please contact us at:

repository@maastrichtuniversity.nl

providing details and we will investigate your claim.
}

Copyright and moral rights for the publications made accessible in the public portal are retained by the authors and/or other copyright owners and it is a condition of accessing publications that users recognise and abide by the legal requirements associated with these

- Users may download and print one copy of any publication from the public portal for the purpose of private study or research.

- You may not further distribute the material or use it for any profit-making activity or commercial gain

If the publication is distributed under the terms of Article $25 \mathrm{fa}$ of the Dutch Copyright Act, indicated by the "Taverne" license above, 


\title{
Basic nursing care: The most provided, the least evidence based - A discussion paper
}

\author{
Sandra M.G. Zwakhalen PhD, RN, Profesor of Nursing Science ${ }^{1}$ (D) | Jan P.H. Hamers PhD, RN, \\ Professor of Care of Older People ${ }^{1}$ | Silke F. Metzelthin PhD, Postdoc Researcher ${ }^{1}$ | \\ Roelof Ettema PhD, RN, Postdoc Researcher ${ }^{2}$ | Maud Heinen PhD, RN, Senior Researcher ${ }^{3}$ | \\ Janneke M. de Man-Van Ginkel PhD, RN, Assistant Professor ${ }^{4,5}$ | Hester Vermeulen PhD, RN, \\ Professor of Nursing Science $^{3}$ | Getty Huisman-de Waal PhD, RN, Senior Researcher ${ }^{3}$ (i) | \\ Marieke J. Schuurmans PhD, RN, Professor Care for Older People P,5 $^{4,5}$
}

\footnotetext{
${ }^{1}$ Department of Health Services Research, Research School CAPHRI, Maastricht University, Maastricht, The Netherlands

${ }^{2}$ University of Professional Education Utrecht, Utrecht, The Netherlands

${ }^{3}$ Radboud University Medical Center, Radboud Institute for Health Sciences, IQ Healthcare, Nijmegen, The Netherlands

${ }^{4}$ Department of Rehabilitation, Nursing Science and Sport, Nursing Science, University Medical Center Utrecht, Brain Center Rudolf Magnus, Utrecht, The Netherlands

${ }^{5}$ Nursing Science, Program in Clinical Health Sciences, University Medical Center Utrecht, Utrecht, The Netherlands

Correspondence

Sandra M.G. Zwakhalen, Department of Health Services Research, Research School CAPHRI, Maastricht University, Maastricht, The Netherlands.

Email: s.zwakhalen@maastrichtuniversity.nl

\section{Funding statement}

The Netherlands Organisation for Health Research and Development (ZonMw) funded the project, project number 520002003 .
}

\begin{abstract}
Aims and objectives: To describe and discuss the "Basic Care Revisited" (BCR) research programme, a collaborative initiative that contributes to evidence-based basic nursing care and raises awareness about the importance of basic nursing care activities.

Background: While basic nursing care serves nearly all people at some point in their lifetime, it is poorly informed by evidence. There is a need to prioritise and evaluate basic nursing care activities to improve patient outcomes and improve the quality of care.

Design: Discussion paper

Method: The discussion presented in this paper is based on nursing literature and theory and supported by the authors' clinical and research experiences. We present the developmental process and content of a research programme called "Basic Care Revisited" (BCR) as a solution to move forward and improve basic nursing care.

Discussion: To prioritise basic nursing care, we propose a research programme entitled "Basic Care Revisited" that aims to create awareness and expand knowledge on evidence-based basic nursing care by addressing four basic nursing care themes (bathing and dressing, communication, mobility, and nutrition) in different settings. The paper discusses a pathway to create a sustainable and productive research collaborative on basic nursing care and addresses issues to build research capacity.

Relevance to clinical practice: Revaluation of these important nursing activities will not only positively influence patient outcomes, but also have an impact on staff outcomes and organisational outcomes.
\end{abstract}

KEYWORDS

basic nursing care activities, evidence-based practice, nursing practice

\section{1 | BACKGROUND}

Nurses are often confronted with basic nursing care activities. To describe nursing, Henderson strongly focused on basic activities nurses should do. As long ago as 1966, Henderson made the following observation:

"The unique function of nurses in caring for individuals, sick or well, is to assess their responses to their health status and to assist 
them in the performance of those activities contributing to health or recovery or to dignified death that they would perform unaided if they had the necessary strength, will, or knowledge and to do this in such a way as to help them gain full of partial independence as rapidly as possible" (Henderson, 1966).

The concept of basic nursing care has been a long-standing central theme postulated by nursing theories and frameworks and has been named and operationalised in various ways (see Table 1).

Kitson, known as one of the key nurse scientists of basic nursing care, has identified 14 of these basic care needs. They include the following: care for communication and education, respiration, eating and drinking, elimination, personal cleanliness and dressing, mobility, rest and sleep, temperature control, expressing sexuality, safety, prevention and medication, dignity, privacy, respecting choice, comfort (including pain management) (Kitson, Conroy, Wengstrom, ProfettoMcGrath, \& Robertson-Malt, 2010). Basic nursing care represents the care that is recognised by patients as being the most necessary and important (Kitson et al., 2010). Therefore, others also have referred to basic nursing care as the fundamentals or essentials of care (Kitson et al., 2010). These terms are often used interchangeably. In this article, we use the term basic nursing care to describe aspects of care that are fundamental to all patients' health and wellbeing, regardless of diagnosis, cultural background or healthcare setting (Kitson et al., 2010).

As illustrated by the case illustration in Box 1, a great deal of the patients' requirements are centred on the work of nurses (Hughes, 2008). A growing body of evidence demonstrates, however, that whenever basic nursing care is lacking it directly affects the quality of care provided in terms of patients' satisfaction and clinical outcomes (Meade, Bursell, \& Ketelsen, 2006; Papastavrou, Andreou, Tsangari, \& Merkouris, 2014). Results of an observational study showed that in facilities where patients' outcomes (assessed by quality indicators such as low rates of falls, pain, etc.) were assessed as "good," staff were more often focused on fulfilling

\section{What does this paper contribute to the wider global clinical community?}

- "Basic Care Revisited" presents a joint research programme that aims to create awareness and expand knowledge of evidence-based basic nursing care on the one hand and create a sustainable and productive research collaborative group to improve basic nursing care on the other hand.

- "Basic Care Revisited" (BCR) addresses four basic nursing care themes, bathing and dressing, communication, mobility, and nutrition, in different nursing care settings. Through this proposed research programme, we will expand the knowledge base of basic nursing care, which be used by nurses in daily practice, by teachers in the education, by national regulatory bodies to promote basic nursing care and quality assurance, and by other international research groups focussing on basic nursing care.

residents' basic care needs (Aiken et al., 2012; Ausserhofer et al., 2014; Rantz \& Zwygart-Stauffacher, 2004). Meanwhile, various publications have confirmed that in the current healthcare context, basic nursing care is an area of major importance (Dick, Patrician, \& Loan, 2017; Feo \& Kitson, 2016). In the UK in 2013, the Stafford Report (Francis, 2013) was published criticising the quality of care provided in hospitals. The report showed, for instance, that a third of the care services investigated failed to meet the required standards for nutrition (Francis, 2013). Examples of unmet basic care needs are numerous and related to all areas of nursing care (Ausserhofer et al., 2014).

When basic nursing care is lacking, this may result in inadequate, incomplete, omitted or even harmful care. There are potentially

TABLE 1 Basic nursing care operationalisations

\begin{tabular}{|c|c|c|c|}
\hline $\begin{array}{l}\text { Nightingale (1860) } \\
\text { (essential elements) }\end{array}$ & Henderson (1964) (human needs) & $\begin{array}{l}\text { Kitson et al. (2010), Kitson and Muntlin } \\
\text { Athlin (2013) (fundamentals) }\end{array}$ & $\begin{array}{l}\text { Englebright, Aldrich, and Lyndon (2014) } \\
\text { (BNC in hospitalised patients) }\end{array}$ \\
\hline $\begin{array}{l}\text { - } \text { pure air } \\
\text { - } \text { pure water } \\
\text { - } \text { efficient drainage } \\
- \text { cleanliness } \\
\text { - light }\end{array}$ & $\begin{array}{l}\text { - breathe normally } \\
\text { - } \text { eat and drink adequately } \\
\text { - eliminate body wastes } \\
\text { - move and maintain desirable pos- } \\
\text { tures } \\
\text { - sleep and rest } \\
\text { - dress and undress } \\
\text { - maintain body temperature } \\
\text { - } \text { keep the body clean } \\
- \text { avoid dangers in the environment } \\
\text { - communicate with others } \\
\text { - worship according to one's faith } \\
\text { - work in such a way that there is } \\
\text { a sense of accomplishment } \\
\text { - play or participate } \\
\text { - learn, discover or satisfy the } \\
\text { curiosity }\end{array}$ & $\begin{array}{l}\text {-communication and education } \\
\text {-respiration } \\
\text {-eating and drinking } \\
\text {-elimination } \\
\text {-personal cleanliness and dressing } \\
\text {-mobility } \\
\text {-rest and sleep } \\
\text {-temperature control } \\
\text {-expressing sexuality } \\
\text {-safety, prevention and medication } \\
\text {-dignity } \\
\text {-privacy } \\
\text {-respecting choice } \\
\text {-comfort (including pain management) }\end{array}$ & $\begin{array}{l}\text {-comprehensive assessment } \\
\text {-periodic clinical reassessment (e.g., vital } \\
\text { signs, intake) } \\
\text {-activities of daily living (e.g., personal } \\
\text { hygiene) } \\
\text {-care management (including coordination } \\
\text { of care team activities) }\end{array}$ \\
\hline
\end{tabular}




\section{BOX 1 Case illustration}

Mr Smith is a 93-year-old man recently admitted to the hospital after a fall at home. The fall caused a hip fracture, and he was admitted for hip surgery. He has a 12-year history of coronary heart disease and some other comorbid age-related conditions such as visual impairment and arthritis. Technically, the surgery was successful. However, Mr Smith has experienced postoperative problems that affect his ability to perform self-care activities independently. $\mathrm{He}$ has become immobile and does not dare to walk to the toilet by himself anymore. As a result, he stays in bed for most of the day even although early mobilisation is known to prevent complications such as pneumonia and thromboembolism. During the last two weeks, he is not eating well and has lost weight. The combination of problems that occurred negatively affected his physical condition and a red wound on the sacrum was recorded. Washing and dressing himself has become even more difficult, and he needs increasing support from nurses on the ward with all kinds of self-care activities. Several times a day, Mr Smith calls for help to fulfil his basic care needs.

negative implications for numerous patient outcomes and patient safety in general (Simpson \& Lyndon, 2017).

Kalisch (2006) provided one of the first reports about failings in basic care and determined nine elements of regularly missed nursing care that may affect patients' outcomes. These include ambulation, turning, delayed or missed feedings, patient education, discharge planning, emotional support, patient hygiene, documentation and surveillance. Not surprisingly, these themes strongly connect to the basic care needs. How many nurses have not witnessed a moment of missed feedings, when a plate of food had been positioned at the patient's bedside and was picked up later in the same condition? More recently, a study by Ball and colleagues found that care left undone was significantly associated with mortality following common surgical procedures in European hospitals (Ball et al., 2017). Moreover, there is a greater demand to register and report on care outcomes for reasons of mandatory administration (Cunningham, Kennedy, Nwolisa, Callard, \& Wike, 2012). Such administrative tasks often described as box-ticking without knowing what these figures and reports really mean for the nursing care that is provided (Cunningham et al., 2012).

The landscape of health care has changed tremendously over the recent decades (Kimberly \& Cronk, 2016), and this has directly affected nursing care. The continuous demand to meet healthcare needs and to provide high quality care at acceptable societal costs is challenging. Consequently, in all settings (including hospital care, home care and long-term care), nurses nowadays are under pressure (Rechel et al., 2013). Every year hospital stays become shorter for more sick and vulnerable people; this, combined with the widespread policy of keeping people at home as long as possible to reduce access to long-term institutional care, has increased the complexity of care and driven nurses away from the essential focus of carethe patients' basic care needs (Ausserhofer et al., 2014).

Basic care activities have become undervalued (Schneider \& Ruth-Sahd, 2015) as these activities may be perceived as of being easy and not worthy of taking up the nurses' time (Wray \& Wild, 2011). Observational studies confirm that nursing staff spends a minimal amount of time performing basic care activities (HuijbenSchoenmakers, Gamel, \& Hafsteinsdottir, 2009; den Ouden et al., 2015). In many nursing care settings, for example, institutional longterm care, the employment of baccalaureate nurses has become extremely rare and widespread variation in nursing education levels has been created (Backhaus, Verbeek, van Rossum, Capezuti, \& Hamers, 2015). Consequently, there has been a tendency for these types of "simple" care activities to be performed by less educated nurses (Danielsson et al., 2014). However, with the continuous increase in complexity of care, these nurses still have to make better quality decision-making, which subsequently needs to be provided by appropriately educated/qualified nurses to provide effective care.

Although international nursing research developed strongly over the past decade and the number of studies is growing fast, not all aspects of basic nursing care are studied. In the area of patient safety (e.g., the prevention of complications) and end of life care, basic nursing care is well informed by evidence, with large numbers of studies on falls (e.g., Cameron et al., 2012; Cusimano, Kwok, \& Spadafora, 2008; Neyens et al., 2011; Oliver et al., 2007; Vlaeyen et al., 2015), and pressure ulcers (Soban, Hempel, Munjas, Miles, \& Rubenstein, 2011; Sullivan \& Schoelles, 2013). However, for basic nursing care, activities like washing, bathing, toileting, feeding and mobilising, evidence of what nurses should do to provide optimal care and improve the patients' outcomes is often lacking. Too often nursing interventions are still guided by experience, intuition and tradition. If nursing care is studied, these studies are mainly descriptive (Mantzoukas, 2009; Richards \& Hamers, 2009). Mantzoukas showed that of 210 papers published in two international nursing science journals in the course of a year, only $15 \%$ addressed research on the impact of nursing interventions that was not descriptive in its approach (Mantzoukas, 2009). A minority of papers were practice related, some of which focused on basic nursing care. There is obviously a need to provide more evidence for nursing interventions in practice. Large gaps remain in the evidence for much of what nurses do in the course of their daily work (Hallberg, 2006) and what nurses should be doing to assure the best care (Institute of Medicine, 2001). Moreover, although nursing research has shown increasing development in specialist areas (e.g., cancer nursing, cardiovascular nursing, neurology nursing), generating and synthesising evidence on generic basic care has received less attention. This is reflected in the overview of systematic reviews on nursing care available from the Cochrane Library (www.cncf.cochrane.org). Here, systematic reviews on important generic care areas (e.g., mobility, cleanliness and dressing, communication) are lacking, both for inpatient and outpatient care and for rehabilitation or community-based nursing. If available 
at all, reviews selected in the "Nursing Care Field" of the Cochrane reviews refer to very specific subtopics of (non-) nursing care in distinct patient groups, such as "speech and language therapy for aphasia in stroke patients" (Brady, Kelly, Godwin, \& Enderby, 2012) or "upper limb exercises in breast cancer patients" (McNeely et al., 2010). Yet, within the growing evidence base of nursing, patients' basic care needs appears to be one of the most understudied areas in nursing research (Juve-Udina et al., 2014; Schneider \& Ruth-Sahd, 2015). To prioritise basic nursing care, this article aimed to describe and discuss the "Basic Care Revisited" (BCR) research programme. $B C R$ is a collaborative initiative that contributes to create awareness and expand knowledge on evidence-based basic nursing care by addressing four basic nursing care themes (bathing and dressing, communication, mobility and nutrition) in different settings. The article discusses a pathway to create a sustainable and productive research collaborative on basic nursing care and addresses issues to build research capacity.

\section{DESIGN}

This discussion paper describes and discusses the initiation and expansion of the BCR research programme. A research programme developed based on nursing literature and theory and supported by the authors' clinical and research experiences.

\section{3 | METHOD}

Through selective analysis of the literature and sharing our experiences, we present a research programme called "Basic Care Revisited" (BCR) as a way to move forward. In this article, we employ Cooke's model which uses six principles of research capacity building to illustrate how we set up our collaborative research programme and build our research community (Cooke, 2005). These six principles include developing linkages and partnerships, building skills and confidence, ensuring the research is "close to practice," developing appropriate dissemination, building elements of sustainability and continuity and investments in infrastructure.

\section{4 | DISCUSSION}

\section{1 | Developing linkages and partnerships}

Building partnership between academics of three different Universities was the seeding of the BCR programme. In 2012, this brought the Dutch professors Jan Hamers (Maastricht University), Marieke Schuurmans (University Medical Center Utrecht) and Theo van Achterberg (Radboud University Medical Centre) to design a joint research programme focusing on basic nursing care. At the time, in 2012, these three professors in nursing science were the only professors in the Netherlands who worked at a University that held a permanent chair in nursing science. By connecting these three key nursing chair holders, we established a strong research partnership before the start of the project. In the process of writing the $B C R$ application, six intended post docs (two from each University) were closely involved in this joint initiative. The professors served as supervisors, and the post docs met several times during the writing process of the application. This interuniversity collaboration provided the opportunity for building intellectual (knowledge) and social (relationship) capital - a prerequisite to set up and complete research programmes on basic care (Griffiths, Wild, Harvey, \& Fenton, 2000). Although this was the first joint research programme, previous academic collaborations already connected them to each other (e.g., active members of the European Academy of Nursing Science). In our opinion, such connection is essential. The initiation of a large research programme like BCR can only be successful if it is based on mutual interest and trust between partners.

This initiative was rewarded a major research grant for the duration of 5-year from The Netherlands Organisation for Health Research and Development (ZonMw) in 2014. This led to a unique interuniversity collaboration between nursing science research groups, known as BCR. BCR aims to support the evaluation of interventions on basic activities in nursing practice by conducting several (randomised) clinical trials.

\subsection{Building skills and confidence}

During the time of the initiating BCR, the three professors acknowledged a strong need for the development of a leadership programme that aims to support post docs and other talented nursing researchers to consolidate their research career. At that time, there was no postdoctoral programme for $\mathrm{PhD}$ graduates in nursing science-while we are convinced that training future talent and leaders is imperative. Therefore, parallel to the BCR joint research programme, a leadership educational programme was developed. This so-called Leadership Mentoring in Nursing Research (LMNR) programme was initiated to support the building of research capacity in nursing science and a future generation of leaders in nursing research. The LMNR programme included 12 postdoctoral researchers (including three BCR post docs) and offered them extensive mentoring and training to further develop skills and build a nursing research network. All were set in the context of career development.

To enhance skills and competencies, feedback and reflection are essential. Therefor, the six post docs and three professors also meet regularly in project meetings to discuss the progress of the research programme and offer mentoring.

\subsection{Ensuring the research is "close to practice"}

The BCR research programme has been built by and is currently undertaken in three academic (nursing) departments in the Netherlands (Maastricht University, Radboud University Medical Centre and the University Medical Centre, Utrecht) in partnership with a large number of care organisations; partnerships were also formed with 
schools of nursing located within universities of applied sciences. In close collaboration with these partners, the core themes of basic nursing care for practice and policy were identified, prioritised and translated into scientific research projects. Therefore, relevant nursing theories and the literature on basic nursing care were first screened for insights into important themes in basic nursing care (Table 1). In addition, nursing themes were included if (i) it concerned frequently occurring basic nursing care issues (e.g., Geurden, Franck, Weyler, \& Ysebaert, 2015; Lahmann et al., 2015) and (ii) the theme was generic, meaning that it was relevant for a broad spectrum of patients and settings (hospital care, home care and nursing home care). For example, mobility limitations are common in older adults or in hospitalised patients; these limitations affect the physical, psychological, and social aspects of a person's life. This culminated in the selection of the four key themes (i.e., bathing and dressing, communication, mobility, and nutrition) are presented in Table 2.

The focus of BCR is on adult patients, as this is the largest group of patients requiring nursing care. To illustrate, one of the intervention studies is described in more detail in Box 2.

TABLE 2 Focus of the BCR studies

\begin{tabular}{|c|c|c|c|c|c|}
\hline & Setting & Intervention aim & Design & Main Outcome & Preliminary evidence \\
\hline \multirow[t]{3}{*}{ Communication } & Hospital & $\begin{array}{l}\text { To evaluate feasibility and } \\
\text { effectiveness of the Tell-us Card } \\
\text { communication tool for improved } \\
\text { patient participation }\end{array}$ & $\begin{array}{l}\text { Multicenter } \\
\text { cluster } \\
\text { Randomised } \\
\text { controlled } \\
\text { early trial } \\
\text { design }\end{array}$ & $\begin{array}{l}\text { Patient participation and } \\
\text { content of cards }\end{array}$ & $\begin{array}{l}\text { Jangland, Carlsson, } \\
\text { Lundgren, and } \\
\text { Gunningberg (2012) } \\
\text { Van Belle et al. (2017) }\end{array}$ \\
\hline & Hospital & $\begin{array}{l}\text { To evaluate feasibility and } \\
\text { effectiveness of a combined } \\
\text { intervention of the Tell-us Card } \\
\text { communication tool and goal setting } \\
\text { for improved patient participation }\end{array}$ & $\begin{array}{l}\text { Cluster } \\
\text { Randomised } \\
\text { controlled } \\
\text { early trial } \\
\text { design }\end{array}$ & $\begin{array}{l}\text { Patient participation, content } \\
\text { of cards and outcomes of } \\
\text { goal setting }\end{array}$ & $\begin{array}{l}\text { Jangland et al. (2012) } \\
\text { Van Belle et al. (2017) }\end{array}$ \\
\hline & $\begin{array}{l}\text { Nursing } \\
\text { Home }\end{array}$ & $\begin{array}{l}\text { To improve the communication } \\
\text { between nursing staff and dementia } \\
\text { residents in the nursing home during } \\
\text { morning care activities. }\end{array}$ & $\begin{array}{l}\text { Clustered } \\
\text { randomised } \\
\text { trial }\end{array}$ & $\begin{array}{l}\text { Verbal and nonverbal } \\
\text { communication }\end{array}$ & Sloane et al. (2004) \\
\hline \multirow[t]{3}{*}{ Nutrition } & Hospital & $\begin{array}{l}\text { To evaluate the feasibility and } \\
\text { effectiveness of an early Nursing } \\
\text { Nutrition Intervention (NNI) in } \\
\text { outpatients planned for surgery }\end{array}$ & $\begin{array}{l}\text { Pilot } \\
\text { Randomised } \\
\text { controlled trial }\end{array}$ & Nutritional intake & $\begin{array}{l}\text { Ravasco, Monteiro-Grillo, } \\
\text { Vidal, and Camilo (2005); } \\
\text { Silvers, Savva, Huggins, } \\
\text { Truby, and Haines (2014); } \\
\text { Leistra et al. (2015) }\end{array}$ \\
\hline & Hospital & $\begin{array}{l}\text { To evaluate nurses' nutritional care } \\
\text { and patients' self-management in the } \\
\text { treatment of disease-related } \\
\text { malnutrition in the hospital. }\end{array}$ & $\begin{array}{l}\text { Pilot } \\
\text { randomised } \\
\text { controlled trial }\end{array}$ & $\begin{array}{l}\text { Loss of appetite and } \\
\text { functional autonomy, delayed } \\
\text { functional recovery, risk of } \\
\text { dysphagia and depressive } \\
\text { symptoms }\end{array}$ & Kruizenga et al. (2016) \\
\hline & $\begin{array}{c}\text { Home } \\
\text { Care }\end{array}$ & $\begin{array}{l}\text { To detect under nourished older } \\
\text { community-dwelling people waiting } \\
\text { for a hospital admission or recently } \\
\text { discharged and support improving } \\
\text { their nutritional status. }\end{array}$ & Preliminary trial & $\begin{array}{l}\text { Malnutrition, BMI and quality } \\
\text { of live }\end{array}$ & $\begin{array}{l}\text { Bell, Bauer, Capra, and } \\
\text { Pulle (2014); Deutz et al. } \\
\text { (2016); Rondanelli et al. } \\
\text { (2016) }\end{array}$ \\
\hline \multirow[t]{2}{*}{$\begin{array}{l}\text { Bathing and } \\
\text { dressing }\end{array}$} & Hospital & $\begin{array}{l}\text { To maintain and restore independency } \\
\text { in bathing and dressing by } \\
\text { stimulating active engagement in } \\
\text { daily nursing care }\end{array}$ & $\begin{array}{l}\text { Stepped wedge } \\
\text { cluster trial }\end{array}$ & ADL functioning & $\begin{array}{l}\text { Resnick, Boltz, Galik, and } \\
\text { Pretzer-Aboff (2012) }\end{array}$ \\
\hline & $\begin{array}{c}\text { Home } \\
\text { Care }\end{array}$ & $\begin{array}{l}\text { To stimulate independency in bathing } \\
\text { and dressing }\end{array}$ & $\begin{array}{l}\text { Early trial } \\
\text { (quasi- } \\
\text { experimental } \\
\text { design) }\end{array}$ & ADL functioning & Resnick et al. (2012) \\
\hline \multirow[t]{2}{*}{ Mobility } & Hospital & $\begin{array}{l}\text { To maintain and restore independency } \\
\text { in mobility by stimulating active } \\
\text { engagement in daily nursing care }\end{array}$ & $\begin{array}{l}\text { Stepped wedge } \\
\text { cluster trial }\end{array}$ & Mobility & Resnick et al. (2012) \\
\hline & $\begin{array}{c}\text { Home } \\
\text { Care }\end{array}$ & $\begin{array}{l}\text { To engage clients in daily and } \\
\text { physical; activities }\end{array}$ & $\begin{array}{l}\text { Early trial } \\
\text { (quasi- } \\
\text { experimental } \\
\text { design) }\end{array}$ & Physical performance & Resnick et al. (2012) \\
\hline
\end{tabular}




\section{BOX 2 Illustration of a study}

Topic: Feasibility and effectiveness "Tell-us Cards" for hospital patients

Theme: Communication

Setting: Hospital

Background: Communication is recognised as one of the basic care activities. Tailored communication can positively contribute to health outcomes known to be crucial for recovery and quality of life. Evidence on interventions to enhance patient participation in basic care is limited. The use of the so-called Tell-us Cards (Jangland et al., 2012) seems a promising intervention to enhance this communication.

Objective: To investigate the feasibility and effectiveness of "Tell-us Cards" on patient participation in basic care in hospital settings.

Design: Cluster randomised controlled early trial design (MRC Framework). Patients of two surgical and two medical wards $(n=140)$ will be included in this study. Before and after the introduction of the intervention, assessments will take place among patients and nurses at these wards. Intervention: The "Tell-us card" is a tool to elicit patients' preferences and needs in basic care. Patients are invited to write down their specific questions and concerns. The cards are handed out to patients admitted to the hospital (daily). Patients and informal caregivers are invited to use the cards to state their preferences. Nurses are instructed to use the cards as a tool in their dialogue with the patient in making care plans, during ward rounds or for discharge information sessions.

We believe that nursing science on basic care should focus on relevant themes and should generate knowledge that is useful for practice. BCR offers a collaborative learning environment for students, researchers and practitioners. The underlying philosophy is that developing evidence through close collaboration between practitioners and educators will serve the future uptake of findings and improve outcomes. To assure closeness to practice, BCR is, for example, partly linked to the living lab of ageing and long-term care. The living lab is a formal multidisciplinary network consisting of Maastricht University, seven large long-term care organisations and Zuyd University of Applied Sciences. This living lab model is a multidisciplinary partnership with joint appointments of living lab staff working both at the university and within a long-term care organisation (Verbeek, Zwakhalen, Schols, \& Hamers, 2013).

From the start of the programme, interprofessional collaboration has been used to co-create interventions, for example, by initiating working groups that consisted of (nursing) care staff and researchers. These working groups met regularly to address such issues as the complex underlying uncertainties of the interventions or to map out the mechanisms and pathways proposed to lead from the intervention to the desired outcomes (Campbell et al., 2007). To illustrate, the post docs working on the nutrition studies are part of the Dutch Malnutrition Steering Group, the national multidisciplinary knowledge centre for the awareness, prevention, identification and treatment of malnutrition. As a result of various initiatives of this group, the last years have shown a clear decrease in the prevalence of malnutrition in the Netherlands.

\subsection{Developing appropriate dissemination}

It is of great importance that knowledge gathered by BCR is disseminated and - in cases where promising effects are demonstrated implemented in daily nursing practice. By ensuring that the research is "close to practice" and partnership between practice and research is build even before the start of the project (e.g., in prioritising the issues addressed), dissemination is a continuous process. This continuous process ensures implementation will be tailored to the needs of end users and overcomes barriers in an early stage. In our opinion, dissemination is enhanced using an iterative process of development. Therefore, the BCR projects are operationalised by the principles of the Medical Research Council (MRC) framework, which aims to develop and evaluate complex interventions (Craig et al., 2008). The MRC framework (Medical Research Council, 2000) provides guidance on the development, evaluation and implementation of complex nursing interventions to improve health and refers to four flexible, iterative stages: Stage 1 development, Stage 2 feasibility/piloting, Stage 3 evaluation and Stage 4 implementation. Key elements of each specific stage are addressed. For example, in the evaluation stage key elements include (i) assessing effectiveness, (ii) understanding the change process and (iii) cost-effectiveness analyses. Within the BCR research programme, following the developmental phase (Stage $1 \mathrm{MRC}$ ) and testing of draft interventions (Stage 2 $\mathrm{MRC}$ ), a series of trials (Stage 3) were performed. According to the MRC (Craig et al., 2008; Medical Research Council, 2000), exploratory trials are an important step in developing and evaluating complex interventions, as they provide relevant information regarding the implementation of specific intervention components and their possible effects on the outcome measures. Furthermore, key components of the chosen methodology can be evaluated, such as recruitment or outcome measures. Finally, unique evidence of intervention effects is provided for the purpose of calculating sample sizes. This information is highly relevant to the process of finalising the intervention and designing a subsequent main trial (Craig et al., 2008) that will be evaluated in a full-powered trial. Within the full trials performed, some generic outcome measures (e.g., satisfaction with care using the general questions of the CQ-index) will be incorporated in all BCR projects. Using this MRC framework enhances the uptake of evidence in practice due to the syntheses of relevant aspect from development to implementation.

Through basic care activities, nurses can contribute to improved functioning, patient comfort and patient safety. To optimise this within the near future, schools of nursing are charged with the 
responsibility of ensuring that nursing students are adequately prepared for delivering best practices. In order to ensure that nurses take ownership of basic nursing care and to ensure that evidence in this area will be incorporated in future student curricula, this research programme has been initiated in collaboration with the universities of applied science. Therefore, as an additional outcome, this project will directly affect capacity development and strengthen the infrastructure for nursing research and practice in the Netherlands.

Dissemination of the BCR findings will focus on implementation in practice through this collaboration with educators in nursing as well as by lay publications and high impact research publications and conference presentations. We will also distribute our findings through lay publications and factsheets and make sure the products and materials are embedded within educational nursing programmes. A website is available that offers free access of BCR-related products, conference abstract and publications (https://www.basiccare revisited.nl).

\section{5 | Building elements of sustainability and continuity}

To stop the invisibility and devaluation of basic nursing care, as described by Feo and Kitson (2016), we would like to invite research groups from universities all over the globe to join this initiative and to focus on similar or different basic nursing care themes and/or fields where nurses provide care. Several universities including Flinders University (Australia), Ghent University (Belgium), Southampton (UK), Aalborg (Denmark) and Exeter (UK) have expressed strong support for the Dutch initiative and underlined the need for more research on basic nursing care. Researchers of these universities even have announced that they are willing to replicate several of the studies that are initiated in the BCR project.

Since the start of the programme, the BCR research community has grown considerably. Figure 1 resembles the BCR community that has been built within two years of the start of the project. The initial project group of three professors and six post docs was extended by eight PhD students and over 100 students (Bachelor and Masters). We believe that a strong international collaboration in this area really could make the change, putting the need for evidence for basic nursing care on the agenda.

Meanwhile, the funding of the related project of the BCR programme has been expanded. For example, on mobility (i.e., increasing mobility at home), an additional research application was funded by The Netherlands Organisation for Health Research and Development (in 2016) that offers the opportunity to perform a full trial (https://clinicaltri als.gov/ct2/show/NCT03293303). Currently, additional funding applications have been submitted, and meanwhile, research on basic nursing care activities is expanded to other prioritised areas. For example, a systematic assessment of nursing low-value care practices in Dutch clinical practice guidelines was performed. Dutch clinical practice guidelines were screened for do-not-do recommendations stating that specific nursing care should be avoided. In total, 66 nursing do-not-do recommendations in 125 clinical practice guidelines were detected. Most recommendations were relevant for the categories safety, prevention and medication of the Fundamentals of Care framework (Kitson et al., 2010).

\subsection{Investments in infrastructure}

In previous years, the Universities that are involved in the BCR project were able to develop a solid infrastructure and incorporate a

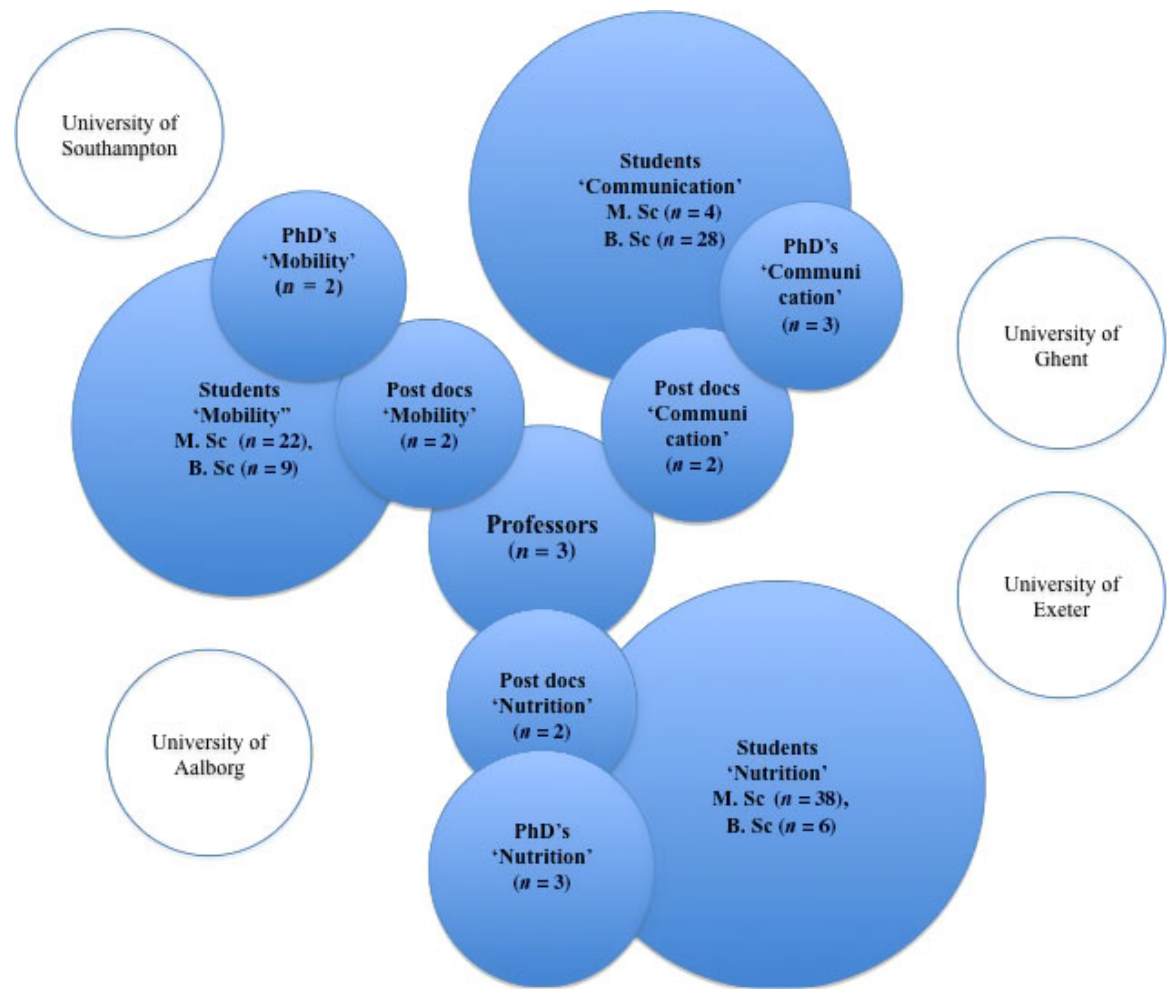

FIGURE 1 BCR research community [Colour figure can be viewed at wileyonlinelibrary.com] 
focus that enabled them to prioritise research activities. This means that University Medical Center Utrecht established research lines that focus on hospital care and home care (e.g., acute events and hospitalisations and on leadership). Maastricht University established research lines that focus on nursing home and home care research (ageing and long-term care). Radboud University Medical Centre established research lines that focus on hospital care (e.g., underpinning fundamentals of care activities and creating and innovative and professional nursing context). However, creating a solid infrastructure is not restricted to a University level. To build research capacity, national support can make a difference in enabling research groups to expand and invest in nursing science. The Netherlands Organisation for Health Research and Development has invested in a longterm funding scheme called "between knowing and doing" that empowered nursing science in the Netherlands. BCR was funded within the third round of this funding scheme.

\section{RELEVANCE TO CLINICAL PRACTICE}

To actually improve the quality of care, we need to highly prioritise basic nursing care. The proposed research agenda of BCR aims to create awareness and expand knowledge on evidence-based basic nursing care by addressing four basic nursing care themes (bathing and dressing, communication, mobility and nutrition) in different nursing care settings. This article discussed the set up and expansion of the BCR programme as a way to move research that focuses on basic nursing care forward. Through this proposed research agenda, we will expand the knowledge base that can be used in daily practice, by teachers in the education of healthcare professionals, by other international research groups on basic nursing care and by national regulatory bodies. Focussing as such on basic nursing care will counterbalance devaluation of basic care and support improving the quality of nursing care.

\section{CONFLICT OF INTEREST STATEMENT}

The authors declare no conflict of interest.

\section{CONTRIBUTIONS}

All authors significantly contributed to the study design, data collection and analysis, and manuscript preparation.

\section{ORCID}

Sandra M.G. Zwakhalen (D) http://orcid.org/0000-0002-7561-5259 Getty Huisman-de Waal iD http://orcid.org/0000-0003-2811-4176

\section{REFERENCES}

Aiken, L. H., Sermeus, W., Van den Heede, K., Sloane, D. M., Busse, R., McKee, M., ... Kutney-Lee, A. (2012). Patient safety, satisfaction, and quality of hospital care: Cross sectional surveys of nurses and patients in 12 countries in Europe and the United States. British Medical Journal, 344, e1717. https://doi.org/10.1136/bmj.e1717

Ausserhofer, D., Zander, B., Busse, R., Schubert, M., De Geest, S., Rafferty, A. M., ... Consortium, R. C. (2014). Prevalence, patterns and predictors of nursing care left undone in European hospitals: Results from the multicountry cross-sectional RN4CAST study. BMJ Quality \& Safety, 23, 126-135. https://doi.org/10.1136/bmjqs-2013-002318

Backhaus, R., Verbeek, H., van Rossum, E., Capezuti, E., \& Hamers, J. P. (2015). Future distinguishing competencies of baccalaureate-educated registered nurses in nursing homes. Geriatric Nursing, 36, 438-444. https://doi.org/10.1016/j.gerinurse.2015.06.012

Ball, J. E., Bruyneel, L., Aiken, L., Sermeus, W., Sloane, D., Rafferty, A. M., ... Griffiths, P. (2017). Post-operative mortality, missed care and nurse staffing in nine countries. International Journal of Nursing Studies, S0020-7489(17), 30176-1. https://doi.org/10.1016/j.jjnurstu. 2017.08.004

Bell, J. J., Bauer, J. D., Capra, S., \& Pulle, R. C. (2014). Quick and easy is not without cost: implications of poorly performing nutrition screening tools in hip fracture. Journal of the American Medical Directors Association, 62(2), 237-243.

Brady, M. C., Kelly, H., Godwin, J., \& Enderby, P. (2012). Speech and language therapy for aphasia following stroke. Cochrane Database of Systematic Reviews, 5, CD000425. https://doi.org/10.1002/14651858.cd 000425.pub3

Cameron, I. D., Gillespie, L. D., Robertson, M. C., Hill, K. D., Cumming, R. G., \& Kerse, N. (2012). Interventions for preventing falls in older people in nursing care facilities and hospitals. Cochrane Database Systematic Review, 12, CD005465. https://doi.org/10.1002/14651858. CD005465.pub3

Campbell, N. C., Murray, E., Darbyshire, J., Emery, J., Farmer, A., Griffiths, F., ... Kinmonth, A. L. (2007). Designing and evaluating complex interventions to improve health care. British Medical Journal, 334 (7591), 455-459. https://doi.org/10.1136/bmj.39108.379965.BE

Cooke, J. (2005). A framework to evaluate research capacity building in health care. BMC Family Practice, 6, 44.

Craig, P., Dieppe, P., Macintyre, S., Michie, S., Nazareth, I., \& Petticrew, M. (2008). Developing and evaluating complex interventions: The new Medical Research Council guidance. British Medical Journal, 29, 337. https://doi.org/10.1136/bmj.a1655

Cunningham, L., Kennedy, J., Nwolisa, F., Callard, L., \& Wike, C. (2012). Patients Not Paperwork - Bureaucracy affecting nurses in the NHS. Retrieved from https://www.qualitasconsortium.com/index.cfm/refe rence-material/fundamentals/patients-not-paperwork/

Cusimano, M. D., Kwok, J., \& Spadafora, K. (2008). Effectiveness of multifaceted fall- prevention programs for elderly in residential care. Injury Prevention, 14, 113-122. https://doi.org/10.1136/ip.2007. 017533

Danielsson, M., Nilsen, P., Ohrn, A., Rutberg, H., Fock, J., \& Carlfjord, S. (2014). Patient safety subcultures among registered nurses and nurse assistants in Swedish hospital care: A qualitative study. BMC Nursing, 13, 39. https://doi.org/10.1186/s12912-014-0039-5

Deutz, N. E., Matheson, E. M., Matarese, L. E., Luo, M., Baggs, G. E, \& Nelson, J. L., ... NOURISH Study Group (2016). Readmission and mortality in malnourished, older, hospitalized adults treated with a specialized oral nutritional supplement: a randomized clinical trial. Clinical Nutrition, 35, 18-26 https://doi.org/10.1016/j.clnu.2015.12. 010

Dick, T. K., Patrician, P. A., \& Loan, L. A. (2017). The value of nursing care: a concept analysis. Nursing Forum, 52, 357-365 https://doi.org/ 10.1111/nuf.12204

Englebright, J., Aldrich, K., \& Lyndon, A. (2014). Defining and incorporating basic nursing care actions into the electronic health record. International Journal of Nursing Scholarship, 46, 50-7. https://doi.org/10. 1111/jnu.12057 
Feo, R., \& Kitson, A. (2016). Promoting patient-centred fundamental care in acute healthcare systems. International Journal of Nursing Studies, 57, 1-11. https://doi.org/10.1016/j.ijnurstu.2016.01.006

Francis, R. (2013). Report of the Mid Staffordshire NHS foundation trust public inquiry. London, England: The Stationery Office.

Geurden, B., Franck, E., Weyler, J., \& Ysebaert, D. (2015). The risk of malnutrition in community-living elderly on admission to hospital for major surgery. Acta Chirurgica Belgica, 115, 341-347.

Griffiths, F., Wild, A., Harvey, J., \& Fenton, E. (2000). The productivity of primary care research networks. British Journal of General Practice 50, 913-915.

Hallberg, I. R. (2006). Challenges for future nursing research: Providing evidence for health-care practice. International Journal of Nursing Studies, 43, 923-927. https://doi.org/10.1016/j.ijnurstu.2006. 07.017

Henderson, V. (1964). The nature of nursing. American Journal of Nursing, 64(8), 62-68.

Henderson, V. (1966). The nature of nursing: A definition and its implications for practice, research, and education. New York, NY: Macmillan.

Hughes, R. (2008). Patient safety and quality: An evidence-based handbook for nurses. Rockville, MD: Agency for Healthcare Research and Quality.

Huijben-Schoenmakers, M., Gamel, C., \& Hafsteinsdottir, T. B. (2009). Filling up the hours: How do stroke patients on a rehabilitation nursing home spend the day? Clinical Rehabilitation, 23, 1145-1150 https://doi.org/10.1177/0269215509341526

Institute of Medicine (2001). Crossing the quality chasm. A New Health System for the 21st Century. Washington, DC: National Academy Press.

Jangland, E., Carlsson, M., Lundgren, E., \& Gunningberg, L. (2012). The impact of an intervention to improve patient participation in a surgical care unit: a quasi-experimental study. International Journal of Nursing Studies, 49, 528-38.

Juve-Udina, M. E., Perez, E. Z., Padres, N. F., Samartino, M. G., Garcia, M. R., Creus, M. C., ... Calvo, C. M. (2014). Basic nursing care: Retrospective evaluation of communication and psychosocial interventions documented by nurses in the acute care setting. Journal of Nursing Scholarship, 46, 65-72. https://doi.org/10.1111/jnu.12062

Kalisch, B. J. (2006). Missed nursing care: a qualitative study. Journal of Nursing Care Quality, 21, 306-313.

Kimberly, J., \& Cronk, I. (2016). Making value a priority: How this paradigm shift is changing the landscape in health care. 13th Oeso World Conference: The Esophagiome II, 1381, 162-167. https://doi.org/10. 1111/nyas.13209

Kitson, A., Conroy, T., Wengstrom, Y., Profetto-McGrath, J., \& Robertson-Malt, S. (2010). Defining the fundamentals of care. International Journal of Nursing Practice, 16, 423-434. https://doi.org/10.1111/j. 1440-172X.2010.01861.x

Kitson, A., \& Muntlin Athlin, A. (2013). Development and preliminary testing of a framework to evaluate patients' experiences of the fundamentals of care: a secondary analysis of three stroke survivor narratives. Nursing Research and Practice, 2013, 572437.

Kruizenga, H., van Keeken, S., Weijs, P., Bastiaanse, L., Beijer, S., Huisman - de Waal, G., ... Thijs, A. (2016). Dutch national undernutrition screening survey in 564.063 patients: Patient with a positive undernutrition screening score stay in hospital 1.4 day longer. The American Journal of Clinical Nutrition, 103, 1026-32. https://doi.org/10. 3945/ajcn.115.126615

Lahmann, N. A., Tannen, A., Kuntz, S., Raeder, K., Schmitz, G., Dassen, T., ... Kotner, J. (2015). Mobility is the key! Trends and associations of common care problems in German long- term care facilities from 2008-2012. International Journal of Nursing Studies, 52, 167-174.

Leistra, E., Eerenstein, S. E., van Aken, L. H., Jansen, F., de van der Schueren, M. A., Twisk, J. W., ... Langius, J. A. (2015). Effect of early individualized dietary counseling on weight loss, complications, and length of hospital stay in patients with head and neck cancer: a comparative study. Nutrition and Cancer, 67, 1093-1103.

Mantzoukas, S. (2009). The research evidence published in high impact nursing journals between 2000 and 2006: A quantitative content analysis. International Journal of Nursing Studies, 46, 479-489. https://doi.org/10.1016/j.ijnurstu.2008.12.016

McNeely, M. L., Campbell, K., Ospina, M., Rowe, B. H., Dabbs, K., \& Klassen, T. P., ... Courneya, K. (2010). Exercise interventions for upperlimb dysfunction due to breast cancer treatment. Cochrane Database of Systematic Reviews, 6, CD005211 https://doi.org/10.1002/ 14651858.cd005211.pub2

Meade, C. M., Bursell, A. L., \& Ketelsen, L. (2006). Effects of nursing rounds: On patients' call light use, satisfaction, and safety. American Journal of Nursing, 106(9), 58-70. https://doi.org/10.1097/ 00000446-200609000-00029

Medical Research Council (2000). A framework for the development and evaluation of RCTs for complex interventions to improve health. London, England: Medical Research Council.

Neyens, J. C., van Haastregt, J. C., Dijcks, B. P., Martens, M., van den Heuvel, W. J., de Witte, L. P., \& Schols, J. M. (2011). Falls in elderly people in long-term care facilities: A systematic review of RCTs. Journal of the American Medical Directors Association, 12, 410-425. https://doi.org/10.1016/j.jamda.2010.07.018

Oliver, D., Connelly, J. B., Victor, C. R., Shaw, F. E., Whitehead, A., Genc, Y., ... Gosney, M. A. (2007). Strategies to prevent falls and fractures in hospitals and care homes and effect of cognitive impairment: Systematic review and meta-analyses. British Medical Journal, 334, 82. https://doi.org/10.1136/bmj.39049.706493.55

den Ouden, M., Bleijlevens, M. H., Meijers, J. M., Zwakhalen, S. M., Braun, S. M., Tan, F. E., \& Hamers, J. P. (2015). Daily (In)activities of nursing home residents in their wards: an observation study. Journal of the American Medical Directors Association, 16, 963-968. https://d oi.org/10.1016/j.jamda.2015.05.016

Papastavrou, E., Andreou, P., Tsangari, H., \& Merkouris, A. (2014). Linking patient satisfaction with nursing care: The case of care rationing - a correlational study. BMC Nursing, 13, 26. https://doi.org/10.1186/ 1472-6955-13-26

Rantz, M. J., \& Zwygart-Stauffacher, M. (2004). Back to the fundamentals of care: A roadmap to improve nursing home care quality. Journal of Nursing Care Quality, 19, 92-94. https://doi.org/10.1097/00001786200404000-00003

Ravasco, P., Monteiro-Grillo, I., Vidal, P. M., \& Camilo, M. E. (2005). Dietary counseling improves patient outcomes: a prospective, randomized, controlled trial in colorectal cancer patients undergoing radiotherapy. Journal of Clinical Oncology, 23, 1431-1438.

Rechel, B., Grundy, E., Robine, J. M., Cylus, J., Mackenbach, J. P., Knai, C., \& McKee, M. (2013). Ageing in the European Union. Lancet, 381(9874), 1312-1322. https://doi.org/10.1016/S0140-6736(12)62087-X

Resnick, B., Boltz, M., Galik, E., \& Pretzer-Aboff, I. (2012). Restorative care nursing for older adults: a guide for all care settings. 2nd edn. New York: Springer Publishing Company.

Richards, D. A., \& Hamers, J. P. (2009). RCTs in complex nursing interventions and laboratory experimental studies. International Journal of Nursing Studies, 46, 588-592. https://doi.org/10.1016/j.ijnurstu.2008. 12.002

Rondanelli, M., Klersy, C., Terracol, G., Talluri, J., Maugeri, R., Guido, D., ... Perna, S. (2016). Whey protein, amino acids, and vitamin D supplementation with physical activity increases fat-free mass and strength, functionality, and quality of life and decreases inflammation in sarcopenic elderly. The American Journal of Clinical Nutrition, 103, 830-40 https://doi.org/103:830-40. doi:10.3945/ajcn.115. 113357

Schneider, M. A., \& Ruth-Sahd, L. A. (2015). Fundamentals: Still the building blocks of safe patient care. Nursing, 45(6), 60-63. https://doi.org/ 10.1097/01.NURSE.0000464987.77315.76 
Silvers, M. A., Savva, J., Huggins, C. E., Truby, H., \& Haines, T. (2014). Potential benefits of early nutritional intervention in adults with upper gastrointestinal cancer: a pilot randomised trial. Supportive Care in Cancer, 22, 3035-3044.

Simpson, K. R., \& Lyndon, A. (2017). Consequences of delayed, unfinished, or missed nursing care during labor and birth. The Journal of Perinatal \& Neonatal Nursing, 31, 32-40. https://doi.org/10.1097/ JPN.0000000000000203

Sloane, P. D., Hoeffer, B., Mitchell, C. M., McKenzie, D. A., Barrick, A. L., Rader, J., ... Koch, G. G. (2004). Effect of person-centered showering and the towel bath on bathing-associated aggression, agitation, and discomfort in nursing home residents with dementia: A randomized, controlled trial. Journal of the American Medical Directors Association, 52, 1795-1804. https://doi.org/10.1111/j.1532-5415.2004.52501.x

Soban, L. M., Hempel, S., Munjas, B. A., Miles, J., \& Rubenstein, L. V. (2011). Preventing pressure ulcers in hospitals: A systematic review of nurse-focused quality improvement interventions. The Joint Commission Journal on Quality and Patient Safety, 37, 245-52.

Sullivan, N., \& Schoelles, K. M. (2013). Preventing in-facility pressure ulcers as a patient safety strategy: a systematic review. Annals of Internal Medicine, 158, 410-416. https://doi.org/10.7326/00034819-158-5-201303051-00008

Van Belle, E., Zwakhalen, S. M. G., Caris, J., van Hecke, A., Huisman de Waal, G., \& Heinen, M. (2017). Tailoring of the Tell-us Card communication tool for nurses to increase patient participation using
Intervention Mapping. Journal of Clinical Nursing, 27(3-4), 621-630. https://doi.org/10.1111/jocn.13968

Verbeek, H., Zwakhalen, S. M. G., Schols, J. M. G. A., \& Hamers, J. P. H. (2013). Keys to successfully embedding scientific research in nursing homes: A win-win perspective. Journal of the American Medical Directors Association, 14, 855-857.

Vlaeyen, E., Coussement, J., Leysens, G., Van der Elst, E., Delbaere, K., Cambier, D., ... Center of Expertise for Fall and Fracture Prevention Flanders (2015). Characteristics and effectiveness of fall prevention programs in nursing homes: a systematic review and meta-analysis of randomized controlled trials. Journal of the American Geriatrics Association, 63, 211-21.

Wray, J., \& Wild, K. (2011). Maintaining practice: Challenges for nurse educators? Nurse Education in Practice, 11, 4-5. https://doi.org/10. 1016/j.nepr.2010.08.001

How to cite this article: Zwakhalen SMG, Hamers JPH, Metzelthin SF, et al. Basic nursing care: The most provided, the least evidence based - A discussion paper. J Clin Nurs. 2018;27:2496-2505. https://doi.org/10.1111/jocn.14296 